\begin{tabular}{|c|c|c|}
\hline BIODIK & $\begin{array}{c}\text { BIODIK: Jurnal IImiah Pendidikan Biologi } \\
\text { ISSN 2580-0922 (online), ISSN 2460-2612 (print) } \\
\text { Volume 7, Nomor 02, Tahun 2021, Hal. 45-54 } \\
\text { Available online at: } \\
\text { https://online-journal.unja.ac.id/biodik }\end{array}$ & BIODIK $(\theta)$ \\
\hline
\end{tabular}

Research Article open 2 ACcess

\title{
Ensiklopedia Keanekaragaman Ikan di Danau Kerinci Sebagai Sumber Belajar Berbasis Android
}

\author{
Encyclopedia of Fish Diversity in Kerinci Lake as an Android-Based Learning Source \\ Wendra Priatama ${ }^{4}{ }^{*}$, Afreni Hamidah², Evita Anggereini ${ }^{3}$ \\ ${ }^{*}$ SMA Negeri 6 Kerinci, Jambi, Indonesia \\ Simpang Empat, Danau Kerinci, Kerinci Regency, Jambi 37172 \\ 2, 3 Universitas Jambi, Indonesia \\ JI. Lintas Jambi-Ma.Bulian KM.15 Mendalo Indah Kec Jaluko Kab. Muaro Jambi 36361-Indonesia \\ *Corresponding Author: wendrapriatama0906@gmail.com
}

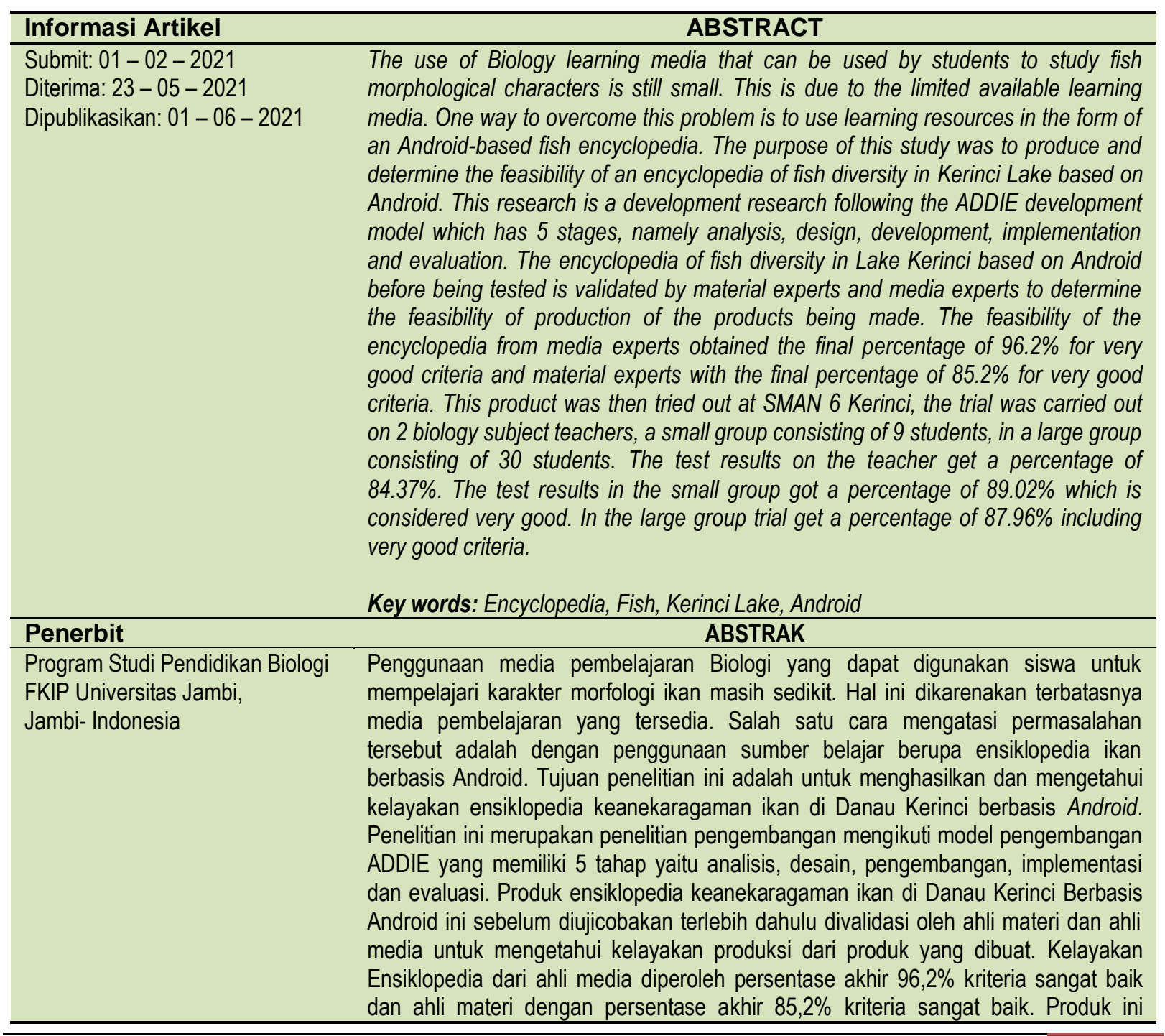


kemudian di ujicobakan di SMAN 6 Kerinci, ujicoba dilakukan pada 2 orang guru mata pelajaran biologi, kelompok kecil, terdiri dari 9 orang siswa, pada kelompok besar terdiri dari 30 orang siswa. Hasil ujicoba pada guru mendapatkan persentase $84,37 \%$. Hasil ujicoba pada kelompok kecil mendapatkan persentase $89,02 \%$ yang termasuk kriteria sangat baik. Pada ujicoba kelompok besar mendapatkan persentase $87,96 \%$ termasuk kriteria sangat baik.

Kata kunci: Ensiklopedia, Ikan, Danau Kerinci, Android

This BIODIK : Jurnal IImiah Pendidikan Biologi is licensed under a CC BY-NC-SA (Creative Commons Attribution-ShareAlike 4.0 International License)

\section{PENDAHULUAN}

Penggunaan Smartphone berbasis Android sangatlah diperlukan dalam kegiatan pembelajaran. Ini dikarenakan fungsi dari Smartphone berbasis Android dapat menjadi perantara komunikasi antara guru dan siswa (Aripin,2018). Smartphone berbasis Android juga bisa menjadi media untuk menyalurkan informasi yang tidak terangkum dalam buku paket. Tak terkecuali pada mata pelajaran biologi. Mata pelajaran Biologi banyak sekali materi-materi abstrak yang memerlukan bantuan media pembelajaran untuk menjelaskan materi yang diajarkan. Materi biologi juga terdapat peristiwa kompleks seperti proses, mekanisme, serta morfologi yang tidak dapat diamati secara langsung (O'day, 2007). Salah satu materi yang memerlukan alat simulasi atau visualisasi adalah materi tentang ikan (Pisces).

Berdasarkan observasi pendahuluan di SMA Negeri 6 Kerinci pada tanggal 25 maret 2019 didapatkan data $69,2 \%$ siswa mengalami kesulitan mempelajari materi ikan salah satunya dalam hal mengidentifikasi karakteristik jenis ikan. Selain itu 61,5\% siswa juga belum mengetahui karakter dan jenis-jenis ikan yang ditemui di sekitar lingkungan tempat tinggal mereka. Siswa menganggap bahwa sumber belajar yang tersedia belum cukup membantu mereka dalam mempelajari karakteristik jenis ikan. Ditinjau dari aspek kebutuhan, 96,1\% siswa sangat membutuhkan sumber belajar dalam bentuk media pembelajaran yang berisi informasi tentang karaktersitik jenis-jenis ikan yang kontekstual.

Salah satu cara yang dapat dilakukan untuk mengatasi persoalan ini adalah dengan mengembangkan media pembelajaran yang berisi informasi mengenai karakteristik jenis ikan yang tidak didapatkan di buku cetak serta dapat digunakan siswa secara mandiri. Salah satu media pembelajaran yang bisa digunakan adalah ensiklopedia. Menurut Sugono., dkk (2008) ensiklopedia adalah buku yang didalamnya berisi informasi mengenai cabang suatu ilmu pengetahuan atau bidang, yang biasanya disusun berdasarkan abjad. Selain itu menurut Prihartanta (2015) bahwa cakupan pembahasan sebuah ensiklopedia juga sangat luas sehingga dapat dijadikan sumber belajar materi yang dibutuhkan oleh siswa.

Kebanyakan ensiklopedia yang tersedia di sekolah saat ini masih dalam bentuk cetak. Hal ini dibuktikan dari dokumentasi observasi di perpustakaan SMA Negeri 6 Kerinci bahwa mayoritas ensiklopedia yang tersedia masih berupa versi cetak. Dengan banyaknya ensiklopedia versi cetak yang tersedia di perpustakaan membuat siswa kurang tertarik untuk menggunakan. Karena disamping ukurannya yang tebal ensiklopedia versi cetak juga didominasi oleh teks sehingga siswa bosan menggunakan. Maka dari itu diperlukan inovasi untuk mengembangkan sebuah ensiklopedia versi digital yang simpel, menarik dan praktis dengan harapan bisa menarik perhatian siswa menggunakannya sebagai sumber belajar. 
Danau Kerinci merupakan salah satu potensi yang bisa dijadikan sumber belajar kontekstual bagi sekolah yang berada disekitarnya. Berdasarkan penelitian Samuel., dkk (2013) bahwa terdapat 16 jenis ikan tergolong ke dalam 8 famili yang hidup di danau Kerinci. Namun, jenis ikan di danau Kerinci yang diketahui oleh siswa masih sangat sedikit. Padahal potensi keanekaragaman ikan dapat dijadikan sebagai media untuk mengenalkan kepada siswa mengenai jenis-jenis ikan khususnya yang terdapat di danau Kerinci (Riana, 2016). Maka dari itu, jenis-jenis ikan yang ada di danau Kerinci dapat direfleksikan menjadi sumber belajar kontekstual berupa ensiklopedia berbasis Android untuk materi kingdom animalia terutama pada submateri ikan (Pisces).

\section{METODE PENELITIAN}

Model pengembangan yang digunakan dalam penelitian ini adalah model ADDIE yang dikembangkan oleh Lee dan Owen (Branch, 2009). Model pengembangan ADDIE memiliki 5 tahap yaitu Analysis, Design, Development, Implementation dan Evaluation. Langkah-langkah pengembangan model ADDIE dapat dilihat pada Gambar.1

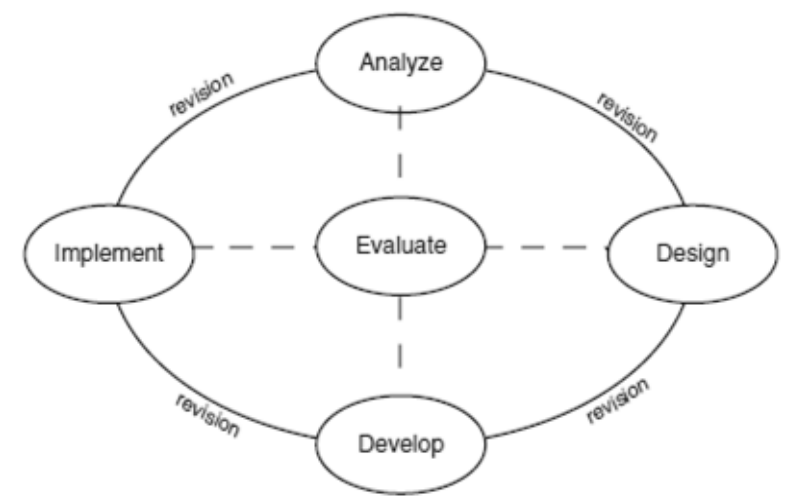

Gambar 1. Prosedur Model ADDIE (Branch,2009)

1. Pada tahap analisis dilakukan identifikasi penyebab permasalahan yang terjadi dalam pembelajaran. Pada tahap ini juga dilakukan identifikasi apakah media benar-benar dibutuhkan oleh siswa.

2. Tahap Desain (Design)

Tahap desain terdiri dari penentuan tim pengembang, penentuan jadwal pembuatan ensiklopedia, menentukan cakupan materi, spesifikasi produk media ensiklopedia, pembuatan storyboard dan menyiapkan sumber daya yang diperlukan.

3. Tahap Pengembangan (Develop)

Pada tahap pengembangan langkah awal yang dilakukan adalah pengambilan sampel ikan di danau Kerinci. Sampel ikan di peroleh dari nelayan Tigo Luhah Tanjung Tanah dan diidentifikasi jenisnya. Setelah semua terkumpul, dilakukan pembuatan produk ensiklopedia keanekaragaman ikan di Danau Kerinci berbasis Android ini dengan bantuan aplikasi Adobe Flash Professional CS6 sampai pada tahap mempublish dalam format apk. Setelah pembuatan produk awal ensiklopedia selesai, langkah selanjutnya adalah validasi dari ahli media dan materi. Validasi produk dibutuhkan untuk mendapatkan saran perbaikan sehingga didapatkan ensiklopedia keanekaragaman ikan di danau Kerinci berbasis Android yang layak. Selanjutnya dilakukan ujicoba produk pada guru biologi kelas X (2 orang), kelompok kecil (9 orang) dan kelompok besar (30 siswa). Angket validasi 
media terdiri dari 20 pertanyaan dan angket validasi materi terdiri dari 22 pernyataan. Angket validasi media memuat pernyataan-pernyataan aspek ukuran, aspek desain grafis, desain materi dan kualitas teknis. Adapun instrument lembar angket validasi media menggunakan kisi-kisi yang dapat dilihat pada Tabel 1.

Tabel 1. Kisi-kisi instrumen validasi ahli media

\begin{tabular}{cl}
\hline \multicolumn{1}{c}{ Aspek } & \multicolumn{1}{c}{ Indikator } \\
\hline & Resolusi layar tampilan ensiklopedia \\
& Desain tampilan eksiklopedia \\
& Font teks yang digunakan \\
Grafis Software (Media) & Audio/sound \\
& Tombol navigasi \\
& Komunikatif \\
& Interaktif \\
\hline \multirow{3}{*}{ Isi/Konten } & Petunjuk penggunaan \\
& Gambar/poto \\
& Konsistensi tata letak \\
& Tipografi \\
\hline \multirow{2}{*}{ Kualitas Teknis } & Kemudahan penggunaan \\
& Kesalahan yang menyebabkan berhentinya ensiklopedia \\
\hline
\end{tabular}

Diadaptasi dari Rusdi (2018) dan BNSP(2014)

Adapun instrument lembar angket validasi media menggunakan kisi-kisi yang dapat dilihat pada Tabel 2. Angket validasi materi memuat pernyataan-pernyataan aspek pengetahuan, isi dan bahasa.

Tabel 2. Kisi-kisi instrumen validasi ahli materi

\begin{tabular}{|c|c|}
\hline Aspek & Indikator \\
\hline \multirow{10}{*}{$\begin{array}{c}\text { Konstruk isi/ } \\
\text { Konten }\end{array}$} & Kelengkapan materi \\
\hline & Kedalaman materi \\
\hline & Keakuratan Materi \\
\hline & Kemutakhiran Materi \\
\hline & Motivasi \\
\hline & Dialogis,Interaktif dan Komunikatif \\
\hline & Petunjuk penggunaan \\
\hline & Kesesuaian dengan perkembangan siswa \\
\hline & Kesesuaian dengan Kaidah Bahasa Indonesia \\
\hline & Penggunaan istilah \\
\hline \multirow{4}{*}{ Grafis } & Penggunaan Font \\
\hline & Kesesuaian gambar \\
\hline & Kualitas gambar \\
\hline & Kejelasan Teks \\
\hline
\end{tabular}

Diadaptasi dari Rusdi (2018) dan BNSP(2014) 
Teknik analisis untuk menghitung persentase tanggapan diukur berdasarkan table 3 yang diambil dari Widoyoko (2014) adalah sebagai berikut:

Tabel 3. Kategori tingkat validitas

\begin{tabular}{cc}
\hline Persentase $(\%)$ & Tingkat Kriteria \\
\hline $76-100$ & Sangat Baik \\
$51-75$ & Baik \\
$26-50$ & Tidak Baik \\
$0-25$ & Sangat Tidak Baik \\
\hline
\end{tabular}

Widoyoko (2014)

4. Tahap Implementasi

Tahap keempat adalah implementasi ensiklopedia yang dilakukan di SMA Negeri 6 Kerinci. Pada tahap implementasi dilakukan Tahap implementasi juga dilakukan uji efektiftas berdasakan data hasil belajar siswa baik kelas eksperimen dan kelas kontrol.

5. Tahap Evaluasi (Evaluation)

Pada tahap ini kegiatan yang dilakukan adalah evaluasi secara keseluruhan apakah produk yang dikembangkan sudah berhasil atau tidak digunakan.

\section{HASIL PENELITIAN DAN PEMBAHASAN}

Danau Kerinci memiliki potensi keanekaragaman hayati ikan yang dapat dioptimalkan sebagai sumber belajar. Potensi keanekaragaman ikan dapat digunakan sebagai media untuk mengenalkan siswa pada jenis-jenis ikan khususnya yang terdapat di Danau Kerinci (Riana, 2016). Hasil identifikasi menunjukkan terdapat empat belas spesies ikan di Danau Kerinci yang terdiri dari 9 famili.

Jenis ikan yang ditemukan digunakan sebagai sumber belajar dalam pengembangan Ensiklopedia Keanekaragaman Ikan di Danau Kerinci berbasis Android. Jenis ikan ini disajikan dalam ensiklopedia yang memuat gambaran umum, karakter morfologi, klasifikasi, status konservasi dan pemanfaatan. Penyajian materi juga menggunakan bahasa yang sederhana dan mudah dipahami oleh siswa SMA.

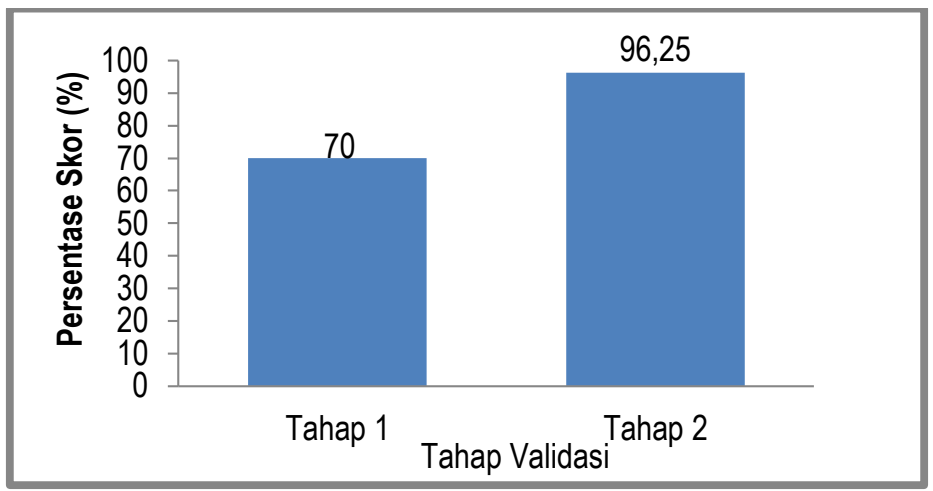

Gambar 2. Proses tahapan validasi ahli media

Pengembagan Ensiklopedia Kenakaragaman ikan di danau Kerinci berbasis Android telah melalui serangkaian tahapan dari model pengembangan ADDIE. Hasil yang diperoleh berupa penilaian dari validator media, validator materi, persepsi guru mata pelajaran Biologi dan respon siswa terhadap 
penggunaan ensiklopedia. Ensiklopedia Keanekaragaman ikan di danau Kerinci Berbasis Android yang telah selesai dibuat, kemudian divalidasi oleh validator media. Proses validasi ini dilakukan sebanyak dua kali. Dari hasil validasi tersebut diperoleh saran dan perbaikan. Adapun hasil validasi tahap pertama diperoleh persentase $70 \%$ dengan kategori baik, kemudian hasil validasi kedua diperoleh persentase $96,2 \%$ kriteria sangat baik.

Tabel 4. Hasil akhir validasi oleh validator media

\begin{tabular}{cccc}
\hline Aspek & Skor & Persentase (\%) & Kriteria \\
\hline Desain grafis & 38 & 95 & Sangat Baik \\
Desain isi/konten & 31 & 96,9 & Sangat Baik \\
Kualitas teknis & 8 & 100 & Sangat Baik \\
Total & 77 & 96,25 & Sangat Baik \\
\hline
\end{tabular}

Berdasarkan Tabel 4. diketahui terdapat tiga aspek yang dinilai kelayakannya pada validasi media yaitu desain grafis software, desain isi/konten dan kualitas teknis. Aspek desain grafis terdiri dari 10 item pertanyaan. Nilai kelayakan pada aspek desain grafis memperoleh skor 38 atau $95 \%$, aspek desain isi/konten memperoleh skor 31 atau $96,9 \%$ dan aspek kualitas teknis dengan skor 8 atau $100 \%$. Dengan demikian secara umum penilaian yang diberikan oleh validator media terhadap ensiklopedia keanekaragaman ikan di danau Kerinci berbasis Android termasuk kategori sangat baik atau sangat layak. Sehingga dapat dinyatakan layak untuk dijadikan sebagai sumber belajar. Hal ini sesuai dengan hasil penelitian Nurhatmi, dkk (2015) dan Jayanti., dkk (2019) bahwa ensiklopedia berbasis Android layak digunakan sebagai sumber belajar.

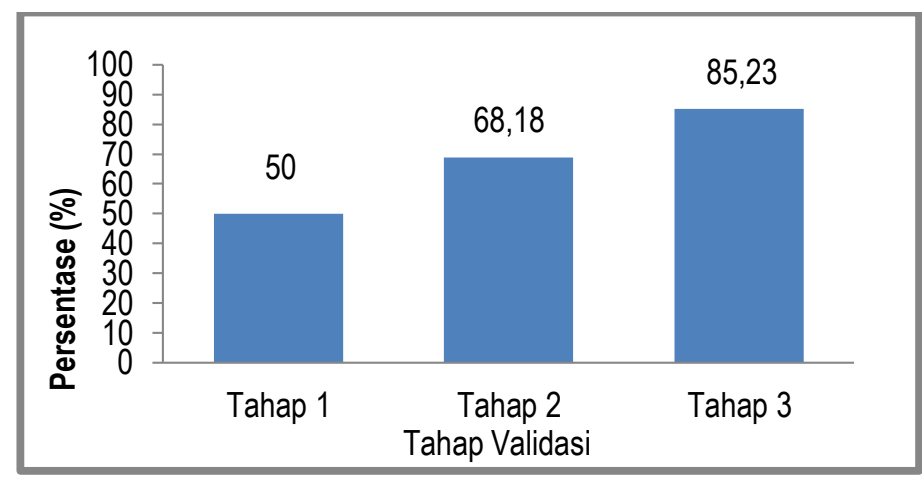

Gambar 3. Proses tahapan validasi ahli materi

Selain dilakukan validasi media, juga dilakukan validasi materi oleh ahli materi. Validasi materi ini bertujuan untuk menilai kelayakan materi yang terdapat di dalam ensiklopedia. Proses validasi ini dilakukan sebanyak tiga kali. Dari hasil validasi tersebut diperoleh saran dan perbaikan. Hasil validasi tahap pertama diperoleh persentase $50 \%$ dengan kategori tidak baik, validasi tahap kedua diperoleh persentase $68,8 \%$ kategori baik, kemudian hasil validasi ketiga diperoleh persentase $85,2 \%$ kriteria sangat baik.

Tabel 5. Hasil akhir validasi oleh validator materi

\begin{tabular}{cccc}
\hline Aspek & Skor & Persentase $(\%)$ & Kriteria \\
\hline Konstruk isi/konten & 54 & 84,38 & Sangat Baik \\
Grafika & 21 & 89,29 & Sangat Baik \\
Total & 75 & 85,23 & Sangat Baik \\
\hline
\end{tabular}


Berdasarkan Tabel 5. diketahui terdapat dua aspek yang dinilai kelayakannya pada validasi materi yaitu konstruk isi/konten dan grafika. Skor kelayakan pada aspek konstruk isi/konten yaitu 54 atau $84,38 \%$ dan termasuk kategori sangat baik. Pada aspek grafika dinyatakan sangat baik dengan skor 21 atau $89,29 \%$. Secara keseluruhan diperoleh skor total 75 atau 85,23\%. Dengan demikian secara keseluruhan materi yang terdapat pada ensiklopedia berbasis Android sudah layak dijadikan sebagai sumber belajar.
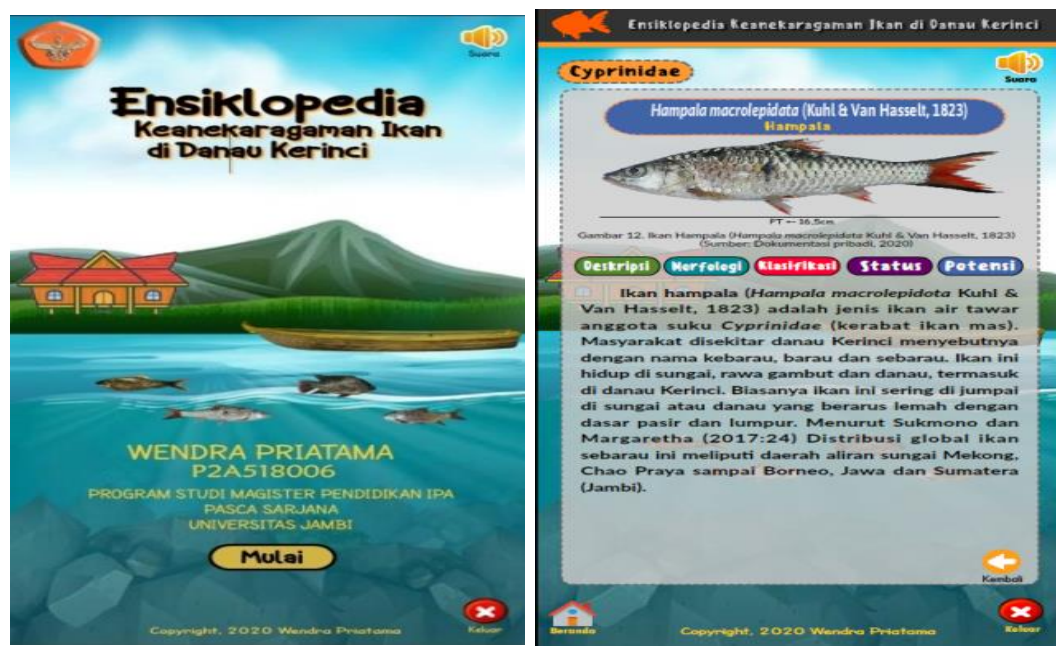

Gambar 4. Tampilan produk ensiklopedia

Setelah ensiklopedia Keanekaragaman ikan di danau Kerinci berbasis Android yang telah dikembangkan dan dianggap layak secara teoritis oleh ahli media dan materi, kemudian produk diujicobakan pada subjek ujicoba. Ujicoba produk dilakukan untuk mendapatkan kelayakan secara praktis. Subjek ujicoba yang digunakan adalah guru mata pelajaran Biologi, Siswa SMA Negeri 6 Kerinci Kelas X MIPA. Ujicoba pada siswa dilakukan pada kelompok kecil dan besar.

Tabel 5. Hasil respon ujicoba guru dan siswa

\begin{tabular}{ccccc}
\hline Ujicoba & Aspek & Skor & Persentase (\%) & Kriteria \\
\hline \multirow{2}{*}{ Guru } & Grafis & 54 & 84,38 & Sangat Baik \\
& Isi/materi & 61 & 84,72 & Sangat Baik \\
& Software & 20 & 83,33 & Sangat Baik \\
& Total & 135 & 84,37 & Sangat Baik \\
\hline \multirow{3}{*}{ Siswa Kelompok } & Grafis & 255 & 88,54 & Sangat Baik \\
Kecil & Isi/materi & 290 & 89,51 & Sangat Baik \\
& Software & 96 & 88,89 & Sangat Baik \\
& Total & 641 & 89,02 & Sangat Baik \\
\hline \multirow{2}{*}{ Siswa Kelompok } & Grafis & 848 & 88,33 & Sangat Baik \\
Besar & Isi/materi & 953 & 88,24 & Sangat Baik \\
& Software & 311 & 86,39 & Sangat Baik \\
& Total & 2112 & 87,96 & Sangat Baik \\
\hline
\end{tabular}

Dua orang guru yang mengajar mata pelajaran Biologi di kelas X SMA Negeri 6 Kerinci diminta responnya terhadap Ensiklopedia keanekaragaman ikan di danau Kerinci berbasis Android. Hasil rekapitulasi angket respon guru berdasarkan Tabel 5. menunjukkan bahwa ensiklopedia sangat baik dengan skor 135 atau 84,37\%. Hasil penilaian pada aspek grafis memperoleh nilai skor 54 atau 84,38\% dengan kategori sangat baik, aspek isi/materi memperoleh skor 61 atau 84,72\% dengan kategori sangat baik serta pada aspek software memperoleh nilai skor 20 atau 83,33\%. Dengan demikian secara 
keseluruhan ensiklopedia keanekaragaman ikan di danau Kerinci berbasis Android mendapatkan respon yang sangat baik dan dapat digunakan sebagai sumber belajar. Hal ini sesuai dengan penelitian Jayanti, dkk (2017) bahwa ensiklopedia dapat digunakan sebagai sumber belajar.

Selanjutnya respon dari 9 orang siswa pada ujicoba kelompok kecil yang terdiri dari siswa berkemampuan rendah, sedang dan tinggi berada pada kategori sangat baik dengan skor 641atau $89,02 \%$. Berdasarkan hasil tersebut Ensiklopedia keanekaragaman ikan di danau Kerinci berbasis Android dapat diterima dengan baik untuk semua siswa dengan kemampuan yang berbeda serta dapat digunakan dalam kelompok besar.

Ujicoba kelompok besar melibatkan 30 orang siswa SMA Negeri 6 Kerinci. Hasil respon siswa kelompok besar terhadap Ensiklopedia keanekaragaman ikan di danau Kerinci berbasis Android berada pada kategori sangat baik dengan skor 2112 atau 87,96\%. Hasil penilaian pada aspek grafis memperoleh skor 848 atau 88,33\% dengan kategori sangat baik. Hal ini dikarenakan komponen grafis ensiklopedia kenakaragaman ikan di danau Kerinci berbasis Android ini dibuat dengan desain yang simpel dan menarik dengan kombinasi warna yang padu dan tidak mencolok.

Pada aspek isi/materi memperoleh skor 953 atau $88,24 \%$ dengan kategori sangat baik. Hal ini dikarenakan penyajian materi pada ensiklopedia keanekaragaman ikan di danau Kerinci berbasis Android ini lengkap, mendalam dan menarik terutama dalam menjelaskan karakteristik ikan-ikan yang ada di danau Kerinci. Selain itu penggunaan foto ikan yang representatif membuat siswa menjadi tertarik dan lebih mudah diingat. Hal ini sejalan dengan pendapat Susilana dan Riyana (2007) bahwa foto bersifat kongkret dan dapat menunjukkan perbandingan objek yang sebenarnya. Diperkuat lagi oleh penelitian Rahman (2011) bahwa penggunaan media gambar/foto dapat menarik perhatian siswa.

Selanjutnya pada aspek sotfware memperoleh skor 311 dengan persentase 86,39\%. Hal ini dikarenakan aplikasi ensiklopedia keanekaragaman ikan di danau Kerinci berbasis Android ini berjalan dengan baik dan tidak ada bug atau error saat digunakan. Selain itu, akses tombol navigasi yang tidak rumit membuat ensiklopedia berbasis Android ini mudah dan nyaman saat digunakan.

Sumber belajar yang didesain dalam bentuk ensiklopedia berbasis Android memiliki keunggulan seperti penggunaannya yang sangat praktis. Hal ini sesuai dengan hasil penelitiam Jengathe dan Rojatkar (2015) bahwa Smartphone berbasis Android sangat mudah digunakan. Selain itu, ensiklopedia berbasis android dapat digunakan kapan dan dimana saja. Hal ini sesuai dengan pendapat Lestari., dkk (2017) bahwa sumber belajar berbasis Android bersifat sangat fleksibel dan portable dalam menyesuaikan waktu dan tempat belajar siswa. Tidak sampai disitu, konsep layar sentuh yang ditonjolkan membuat siswa dapat berinteraksi langsung dengan media sehingga lebih mudah mengakses materi yang ingin dipelajari (Fatmala \&Yelianti, 2016).

Selain memiliki keunggulan dalam aspek kepraktisan, ensiklopedia ini juga memiliki keunggulan dalam aspek konten. Ensiklopedia ini menyajikan konten materi yang menarik dan kompleks seperti karakteristik ikan, habitat, manfaat serta status konservasinya yang kontekstual dengan kehidupan siswa. Menurut Noviar dan Sulistiyawati (2014) bahwa materi yang disajikan dalam ensiklopedia bersifat kontekstual (mengaitkan materi dengan dunia nyata siswa) dan penyajian yang menarik sehingga dapat menambah minat belajar siswa. Ditambah lagi, adanya kombinasi materi dengan animasi dan foto membuat informasi yang mereka terima menjadi lebih kongkret. Sehingga dapat menarik minat dan menambah pengetahuan siswa mengenai karakteristik ikan, habitat, manfaat dan status konservasinya. Hal ini sejalan dengan penelitian Zhafirah dan Aisiah (2019) bahwa penggunaan ensiklopedia dapat menambah wawasan dan pengetahuan siswa. Diperkuat lagi dengan hasil penelitian Wibowo, dkk 
(2019) bahwa kemenarikan materi yang disajikan dalam ensiklopedia sumber daya alam dapat membangkitkan rasa suka siswa sehingga tertarik untuk membacanya.

\section{SIMPULAN}

Berdasarkan hasil penelitian dan pengembangan ensiklopedia keanekaragaman ikan di danau Kerinci berbasis Android telah berhasil melewati tahap validasi dari para ahli media dan ahli materi. Hasil validasi ahli media memperoleh skor 77 atau $96,2 \%$ dengan kategori sangat baik dan validasi ahli materi memperoleh skor 75 atau $85,23 \%$ dengan kategori sangat baik. Respon yang diberikan oleh guru mata pelajaran biologi memperoleh skor 135 atau 84,37\% dengan kategori sangat baik serta siswa pada kelompok kecil memperoleh skor 641atau 89,02\% dan kelompok besar memperoleh skor 2112 atau $87,96 \%$ kategori sangat baik. Dengan demikian dapat diambil kesimpulan bahwa ensiklopedia yang telah dikembangkan dapat dijadikan sebagai sumber belajar pada materi animalia untuk kelas $\mathrm{X}$ SMA.

\section{RUJUKAN}

Aripin, I. (2018). Konsep Dan Aplikasi Mobile Learning Dalam Pembelajaran Biologi. BIO EDUCATIO:(The Journal of Science and Biology Education), 3(1).

Branch, M.R. (2009). Instructional Design: The ADDIE Approach. USA: University of Georgia.

Fatmala, D., \& Yelianti, U. (2016). Pengembangan media pembelajaran multimedia interaktif berbasis Android pada materi plantae untuk siswa SMA menggunakan Eclipse Galileo. Biodik, 2(1).

Jayanti, N., Widiyaningrum, P., dan Setiati, N. (2019). The Digital Encyclopedia of Butterflies in Jatibarang Reservoir as The Supplement of Biodiversity Teaching Material in Senior High School. Journal of Innovative Science Education, 8 (3), 264-270.

Jengathe, G dan Rojatkar, D.V. (2015). Use of Android in Education System, International Journal of Electrical and Electronics Research, 3(1): 113-137.

Lestari, H., Vivanti, D., \& Miarsyah, M. (2017). Pengembangan Bahan Ajar Berbasis Android Dalam Meningkatkan Pemahaman Siswa Pada Materi Metabolisme. In Prosiding Seminar Pendidikan Biologi Universitas Negeri Jakarta Tema:"Pembelajaran Biologi Abad Ke-21”, 1 (1) : 1-13.

Noviar, D., dan Sulistiyawati, S. (2013). Pengembangan Ensiklopedi Ipaterpadu Berbasis Potensi Lokal Sebagai Bahan Ajar Mandiri Bagi Siswa SD/MI. In Proceeding Biology Education Conference: Biology, Science, Enviromental, and Learning (Vol. 11, No. 1, pp. 1060-1068).

Nurhatmi, J., Rusdi, M., dan Kamid, K. (2015). Pengembangan Ensiklopedia Digital Teknologi Listrik Berbasis Contextual Teaching and Learning (CTL). Edu-Sains: Jurnal Pendidikan Matematika dan IImu Pengetahuan Alam Universitas Jember, 4(1).

O'day, D. H. (2007). The Value Of Animations In Biology Teaching: A Study Of Long-Term Memory Retention. CBE-Life Sciences Education, 6(3), 217-223.

Prihartanta, W. (2015). Ensiklopedia Umum (Nasional). Jurnal Adabiya, 5(85), 1-14.

Rahman, A. A. (2011). Penggunaan Media Gambar dalam Meningkatkan Hasil Belajar Siswa Kelas VI SD Negeri I Peusangan Bireuen Aceh. Madrasah: Jurnal Pendidikan dan Pembelajaran Dasar, $3(2)$.

Riana, L., Hardigaluh, B., \& Wahyuni, E. S. (2016). Media Flipchart Tingkat Keanekaragaman Hayati X SMA Hasil Inventarisasi Ikan Tangkapan Nelayan Padang Tikar (Doctoral dissertation, Tanjungpura University). 
Samuel., Suryati, N.K., Adiansyah, V., Pribadi, D., Pamungkas, Y.P., dan Irawan, B. (2013). Laporan Teknis 2013 Penelitian Bioekologi dan Kajian Stok Ikan di Danau Kerinci Provinsi Jambi. Palembang : Kementerian Kelautan dan Perikanan.

Sugono, D., Sugiyono., dan Maryani,Y. (2008). Kamus Bahasa Indonesia. Jakarta: Pusat Bahasa Departemen Pendidikan Nasiona.I .

Susilana,R dan Riyana, C. (2007). Media Pembelajaran. Bandung: CV Wacana Prima.

Wibowo, D. A., Poerwanti, E., dan Kuncahyono, K. 2019. Pengembangan Buku Enterdal (Ensiklopedia Tematik Sumber Daya Alam) Tema 3 Peduli Terhadap Makhluk Hidup Untuk Siswa Kelas IV Sekolah Dasar. Jurnal Holistika, 3(2), 89-98.

Widoyoko, E. P. (2014). Teknik Penyusunan Instrumen Penelitian. Yogyakarta : Pustaka Pelajar.

Zhafirah, E., dan Aisiah, A. (2019). Pengembangan Ensiklopedia Kerajaan-Kerajaan Hindu-Budha di Nusantara sebagai Sumber Belajar di SMA. Jurnal Halaqah,1 (4), 469-484. 